\title{
WHEN THE GALLIC VILLAGE STRIKES BACK: THE POLITICS BEHIND ‘NEW WAYS OF WORKING' PROJECTS ${ }^{1}$
}

\author{
Grégory JEMINE \\ HEC - Management School - Université de Liège \\ Christophe DUBOIS \\ Faculty of Social Sciences - Université de Liège \\ François PICHAULT \\ HEC - Management School - Université de Liège \\ Management, 20(2), 146-170.
}

${ }^{1}$ This paper is a preprint, self-archived version of an original article. Please use the following reference for citing: Jemine, G., Dubois, C., \& Pichault, F. (2020). When the Gallic Village Strikes Back: The Politics Behind "New Ways of Working" Projects. Journal of Change

In the last decade, the interest of managers and professionals for New Ways of Working (NWoW) has grown rapidly, as evidenced by multiple firms claiming to implement "NWoW workspaces" in Belgium and in the Netherlands. NWoW is often used as a convenient umbrella term to designate a set of organizational adjustments that include open and "flexible" workspaces, new IT tools, as well as cultural and managerial transformations believed to be "innovative". While the academic literature has investigated several cases of NWoW workspaces through post-occupancy studies, there is at the present time no research available on the change process leading to these transformations. The ambition of the paper is to conceptualize NWoW as being projects of organizational change that are subject to politics and power games. Through an empirical study of a multi-site media company implementing a NWoW project, the paper illustrates three major implications of a political conception of NWoW. First, the ability of local actors to bargain around the project and to twist the strategic intentions of the deciding authorities is highlighted. Second, the study underlines the crucial role of key intermediaries for designing NWoW projects. Third, participative approaches of change are critically discussed. The paper also provides recommendations for future research on NWoW.

Keywords: New Ways of Working, organizational politics, organizational change, case study, NWoW, participative management

Making A Difference: In all kinds of sectors, New Ways of Working are flourishing, promoting so-called "innovative" workplaces, digital tools, and managerial transformations. In their enthusiasm and eagerness to dismantle the "old" organizations and to promote "new" ones, the advocates of NWoW have largely concealed the change processes leading to these transformations and downplayed the importance of organizational politics - often vaguely alluded to as "resistance behaviors". Drawing on a study of a media company, the paper illustrates how local actors actively bargain to alter a NWoW project, and argues that political games are a crucial challenge for the management of such transformations. 


\section{INTRODUCTION}

In Belgium and in the Netherlands, the last decade has seen a marked increase in managerial discourses promoting "New Ways of Working" (NWW, or NWoW) in organizations. These discourses build on a shared, dual assumption that the world of work faces unprecedented changes and that bureaucratic organizations are not properly equipped to respond to those changes (Bijl, 2011; Kok et al., 2015). Based on these assumptions, partisans of NWoW suggest a set of solutions which, despite slight local variations, encompass relatively similar spatio-temporal reconfigurations of work contexts, cultural and managerial transformations, and technological innovation, albeit to varying degrees (Aroles et al., 2019; De Leede, 2017). While several academic contributions studied the visible effects of such projects, for instance on employee engagement (Gerards et al., 2018) on knowledge sharing (Kok et al., 2015) and on productivity (De Leede, 2017), the processes of NWoW adoption in organizations remain unclear. The existing literature on NWoW, which has remained primarily interested in the study of the consequences and effects of NWoW environments, has neglected the political processes through which NWoW change projects are shaped and negotiated by intermediary actors and subject to power games and individuals' strategies.

Consequently, building on the political approach to the study of organizations (Pfeffer \& Salancik, 1977; Crozier \& Friedberg, 1980), the paper aims to explore the role of power games and bargaining in the adoption of NWoW, hence suggesting an alternative, political and processual conceptualization of NWoW. Relying on a case study in a multi-site media company implementing a NWoW project, three important gaps in NWoW studies are addressed. First, the paper emphasizes the ability of key peripheral actors to seize a transformation project designed by the strategic instances and to reframe this project according to their own interests and objectives. Contrary to the existing literature on NWoW, which has paid little attention to the strategies deployed by local actors to interfere with NWoW projects, the paper argues that the political behaviors of these actors are of crucial importance for understanding how NWoW projects take shape. Second, the central role of intermediaries and mediators in the implementation process of NWoW projects, which has been insufficiently problematized so far, is underlined. Third, the paper critically investigates the so-called "participative" approach to change that is most often promoted along with NWoW projects. Ultimately, rather than depicting NWoW as mere "innovative workplaces" (Taskin \& Ajzen, 2015), the paper develops a conceptualization of NWoW as an intricate process of organizational change in which local actors and mediators opportunistically exploit their own margin of participation in order to obtain additional resources for themselves.

\section{NWOW, ORGANIZATIONAL CHANGE, AND POWER: A LITERATURE REVIEW}

In the past twenty years, the management fashion known as "New Ways of Working" has quickly expanded through multiple sectors, as evidenced by several projects undertaken in Dutch and Belgian companies, such as, among others, Interpolis in 1998, Microsoft Netherlands in 2005, Rabobank in 2006, and AXA Belgium in 2014 (Dufresne et al., 2018; Kingma, 2018; Jemine et al., 2019). These companies have committed to a relocation of their activities into redesigned and supposedly "flexible" workspaces, while implementing new IT tools, new work practices such as remote working and paperless working, and cultural transformations promoting employees' autonomy and objective-based management. The label "NWoW" is conveniently used to designate these transformations. Several academic contributions have already studied the effects and impacts of "NWoW workspaces" on 
employees, managers, teams and organizations (e.g. Kok et al., 2015; Gerards et al., 2018; Kingma, 2018). However, this paper holds that the change processes through which NWoW projects are being implemented and managed remain understudied. Particularly, the actors involved into the design process of these projects have so far received little attention.

It appears that the few existing studies that have given some consideration to the organizational members in NWoW projects have systematically downplayed their importance in two significant fashions. First, they are often sketchily depicted as mere "resisters" who have to be convinced and enrolled, in such a way that their own interests and agenda remain mostly unknown. For instance, Moll and De Leede emphasize the importance of "reducing resistance and seeking support (...) to facilitate a successful implementation [of NWoW projects]" (2015, p. 99), hence promoting a somewhat passive view of local actors in which what "resistance" entails is left unexplored. For their part, Gerards and colleagues merely state that implementing NWoW "may require substantial periods of adjustments", without further investigation of how exactly such "adjustments" occurs in practice (2018, p. 19). While Kingma $(2018$, p. 5) mentioned that decision-makers willing to implement a NWoW project in a Dutch insurance broker "encountered scepticism and resistance", he did not explained further why or how those behaviors of resistance were deployed. Persistent shadow areas thus remain in the understanding of how NWoW projects are being designed and implemented.

Furthermore, a second issue with existing accounts of the implementation of NWoW projects is of conceptual nature. Existing research is mostly built around the sole objective of understanding the managerial implications or the "effects" of NWoW projects (e.g. Brunia et al., 2016; Gerards et al., 2018). To fulfil that purpose, authors usually frame NWoW around a set of "constitutive dimensions" or "characteristics", such as time flexibility, spatial flexibility, output-based management, and collaborative work practices (Ajzen et al., 2015; Gerards et al., 2018; Van Steenbergen et al., 2018). As a result, the pseudo-theoretical construct of NWoW itself takes precedence in the analyses, at the expense of power relationships, controversies, and bargaining strategies, which often go unreported. In this paper, we would like to suggest an alternative, constructionist (Czarniawska, 2001) approach to NWoW deriving from power-based theories (Crozier \& Friedberg, 1980), in which NWoW projects are first and foremost defined as processes of negotiations between decision-makers and local actors, of which "NWoW" appears to be a mere ingredient among others. To this end, the paper investigates three overlooked dimensions of the change process supporting NWoW projects: power, intermediaries, and participative change management. These three theoretical perspectives are introduced below.

\section{Power and organizational change}

It has been demonstrated time and time again that, in organizations, no actor or group of actors is able to fully gain control over all the activities performed by the organization (Crozier \& Friedberg, 1980; Crozier \& Thoenig, 1976; Salancik \& Pfeffer, 1977). A major consequence for the study of NWoW projects is that the examination of the original, managerial intentions to commit to such a project is not sufficient to grasp the process of NWoW design. Instead, research should investigate the interactions between various coalitions of actors and meaningful "subunits" who manage, through negotiation, to affect the design of NWoW projects and the managerial plans (Lines, 2007; Salancik \& Pfeffer, 1974; Vallas, 2006). From a political perspective, the stabilized, visible NWoW workplace that has been extensively studied by researchers inevitably results from a process of clashes between individuals' strategies, of moments of negotiation, opposition and twists, alliances and compromises 
(Cabantous \& Gond, 2011; Crozier \& Friedberg, 1980; Vallas, 2006). Surprisingly, the literature on NWoW has so far paid no attention to these dynamics of collective action.

In line with previous literature on power relationships, the present paper assumes that organizations are made of actors and groups of actors with their own interests and agendas (Salancik \& Pfeffer, 1974; Vallas, 2006), who negotiate with each other and deploy rational strategies to meet their objectives (Crozier, 1961; Crozier \& Friedberg, 1980). The political view of organizations further emphasizes the shared and relational nature of power, that is, the acknowledgment that no single group of actors is able to fully control all the activities in an organization (Salancik \& Pfeffer, 1977). It follows that, confronted with a NWoW project, a multiplicity of organizational members are likely to weigh in on the process of implementation and on its outcome (Vallas, 2006). What determines their capacity to do so is their margin of liberty for action - commonly called "power" (Crozier \& Friedberg, 1980, p. 32).

Power has been described as a fundamental mechanism in the life of organizations, and implies actors' ability "to get things done the way [they] want them to be done" (Salancik \& Pfeffer, 1977, p. 4) through a range of possible strategies they can deploy (Crozier \& Friedberg, 1980). In the "coalitional" view of organizations (Pfeffer \& Salancik, 1977), key sources of power extend the actors' margin of liberty. For instance, those who possess and are able to mobilize rare and valuable resources in an organization are likely to have substantial bargaining opportunities as a result (Salancik \& Pfeffer, 1977). Similarly, as multiple studies have shown (e.g. Crozier, 1961; Salancik \& Pfeffer, 1977), the ability of an individual or group to master the critical zones of uncertainty within an organization is a valuable source of power. Following this line of reasoning, organizational subunits and local actors possessing valuable resources and mastering critical zones of uncertainty should be in an advantageous position to interfere with organizational change initiated by the top management.

Hypothesizing that local actors can wield power early in NWoW projects implementation is all the more relevant since what "New Ways of Working" mean remains an open question. For instance, while it is clear that NWoW projects should embed "alternative office designs" (Kingma et al., 2019) and "flexible work practices" (Aroles et al., 2019), previous research has shown that such abstract discourses remained ambiguous and difficult to operationalize in practice (Jemine et al., 2019). Multiple interpretations of what an "alternative workplace" or a "flexible work practice" should be could arise. In that sense, NWoW projects may be viewed as processes of organizational change that are particularly prone to uncertainty and ambiguity, and, by extension, to bargaining opportunities (Crozier \& Friedberg, 1980). Relying on these bargaining opportunities, local actors in organizations might substantially influence the development of NWoW projects initially designed by the deciding instances.

\section{Indispensable intermediaries in NWoW projects}

Studies on organizational change have repeatedly emphasized the central role of key individuals who, through their successful investment into power games and negotiations, manage to become indispensable in the change process (Callon, 1986; Crozier \& Friedberg, 1980). These indispensable actors may gradually acquire a considerable influence, without necessarily being the ones with the formal authority to initiate strategic projects or make strategic decisions (Callon, 1986). For instance, speaking of "entrepreneurs" is a common and convenient way to designate the actors who successfully manage to use their available resources in order to pursue their interests and seize opportunities in the course of change projects (Garud et al., 2007). A focus on entrepreneurs involved in a change 
process may reveal the strategies they deploy and the work they do in order to alter their organizational contexts (Lawrence \& Suddaby, 2006). One might also be tempted to describe these actors as "marginaux-secants" - change agents able to use a particular organizational positioning to constrain organizational transformations (Castel \& Friedberg, 2010). In an actor-network perspective, intermediaries may be depicted as "translators" - actors able to develop networks and to mobilize devices to support change processes (Leca et al., 2006). These multiple conceptualizations have repeatedly emphasized the role of intermediaries in projects of organizational change (Castel \& Friedberg, 2010).

Given this profusion of theoretical developments around "entrepreneurs", "mediators" and "translators" (Bergeron \& Castel, 2015), it is strikingly surprising that existing studies of NWoW projects have so little to say about such intermediary actors. Because most of the actual studies on NWoW take the form of ex post assessments of working environments (e.g. Brunia et al., 2016; De Leede, 2017; Gerards et al., 2018), they do not provide insights on the key actors who made these environments exist in the first place. Yet, as the managerial and consultancy discourses promoting New Ways of Working simultaneously emphasize spatial transformations, technological overhauls, and cultural changes (Ajzen et al., 2015; De Leede, 2017; Kingma, 2018), one might expect a variety of experts architects, space designers, IT specialists, HR practitioners, project managers - to be needed for the conduct of such projects. In other words, it is hard to believe that NWoW projects may be carried out without the intervention of any intermediary actors. Consequently, the paper suggests adopting a particular focus on the "intermediaries" who play a major role in the change process underlying NWoW projects (Crozier \& Thoenig, 1976). In doing so, the paper aims to overcome the radical and simplistic dichotomy between "decision makers" and "resisters" that is still to be found in many studies of NWoW.

\section{Participative change management in NWoW projects}

Participation in change processes is a well-known research topic that has received steady attention in management studies (Alutto \& Belasco, 2006; Dyson \& Foster, 1982; Lines, 2004; Nielsen \& Randall, 2012). "Participative" management techniques consist in involving employees in decision making (Pardo-del-Val et al., 2012) to an extent that may vary in scope and intensity from consultation and indirect participation to formal, direct, and representative participation (Ashmos \& McDaniel, 1996; Lines, 2004). Such techniques have been supported by various studies, as a higher level of participation in strategic decisions may, among others, foster employees' trust in management (Giangreco \& Peccei, 2005; Lines et al., 2005), reduce cynicism (Brown \& Cregan, 2008) as well as emotional resistance to change (Smollan \& Sayers, 2009), and generates commitment (Pardo-del-Val et al., 2012). Authors have also underlined that participative management techniques were often associated with positive attitudes towards change and better decisional outcomes (Lines et al., 2005). Conversely, several studies on participation have produced inconclusive results. For instance, the relationship between participative methods and change effectiveness has been repeatedly questioned (Dyson \& Foster, 1982; Elbanna, 2008). Risks of reverse progress or lack of focus have also been pointed at (Russ, 2008). Participative management, therefore, remains a controversial object of research up to this day.

The managerial philosophy underlying NWoW usually emphasizes empowerment, autonomy, and democracy at work as important "values" or "dimensions" of NWoW (Bijl, 2011; De Leede, 2017; Taskin et al., 2017). Consultancy books and reports about NWoW hold that "employees demand greater freedom (...), less control, less command, fewer rules, less rigidity” (Bijl, 2011, p. 27) and recommend 
to "endow greater responsibility to autonomous teams" (Metz \& Noizet, 2017, p. 2). If taken seriously, these discourses should impact the change management practices supporting the introduction of NWoW-labelled projects in organizations. Indeed, one may expect companies claiming to implement such projects to engage "in more democratic and participative governance systems" (Taskin et al., 2017 , p. 72). It has been acknowledged that participative management techniques were particularly in line with democratic values and aspirations (Lines, 2004). Yet, empirical studies have provided very limited analyses of participative management methods in NWoW projects. At best, some authors have suggested to consider a high level of involvement of end-users into the design of NWoW projects to be a "good practice" (Brunia et al., 2016), and employee participation in the change process a "success factor" in the implementation of NWoW projects (De Leede, 2017; Van Steenbergen et al., 2018). At the present time, very little is known about the use and the effects of participative methods of change management in the development of NWoW projects.

The political perspective adopted in this paper may contribute to the theoretical debate on participation by challenging the common assumption that participative management techniques reduce resistance to change (Erwin \& Garmon, 2010; Lines, 2004). If we assume that individuals adopt rational and opportunistic behaviors (Crozier \& Friedberg, 1980), they may judge at any time whether their participation to the change process is likely to benefit their own interests (Friedberg, 1988). What matters, beyond the management techniques being deployed, are the forms of participation that are ultimately visible as well as the results obtained through these forms (Friedberg, 1988). Several studies have illustrated that, contrary to popular belief, participative techniques did not always result in stronger commitment because employees were not always willing to participate in decision-making (Alutto \& Belasco, 2006) or preferred to use informal networks instead of the formal participation channels (Denyer et al., 2011). These research results are illustrations that actors' strategic behaviors play a more important role than the formal strategies being promoted and deployed (Friedberg, 1988). As Russ (2008) has emphasized, participative approaches may produce unintended consequences and generate significant ambiguity. Therefore, we suggest investigating how local actors confronted with a NWoW project and invited to participate in its design can make a strategic use of their own participation.

To summarize, the paper offers a study of the design process of a NWoW project by adopting a political perspective and paying close attention to (1) power games and bargaining opportunities, (2) key intermediaries involved in the change process, and (3) participative techniques and their implications. For a period of nine months, the authors performed an ethnographic study of a NWoW project conducted in a multi-site media company. The analysis focused on the negotiation process taking place between the headquarters and a geographically remote site.

\section{Methodology}

The study is based on a nine-month qualitative research of a public media company of approximately 2000 employees, which operates in Belgium at a total of six sites. In 2014, the executive committee initiated a transformation project which was first worked on by a designated Taskforce located in the company headquarters. Progressively, as it was made clear that the project would involve a cultural transformation of the whole organization, the question of the inclusion of the local sites was raised. The present study analyzes the power relationships between the headquarters and one of the five local sites. The negotiation process between the organization's center and periphery was engaged at the end of 2017, and went on for a year. We investigated the managerial intents of the executive 
committee to implement a transformation project, the initial positioning of the actors from the periphery, and the negotiation process between both parties.

\section{Data collection}

The process of data collection, which embeds a mix of semi-structured interviews and non-participant observation, is summarized in the table below. Because in-depth interviews are an advisable method for understanding how power is distributed in an organization (Crozier \& Thoenig, 1976), managerial intents were investigated through the realization of semi-structured interviews with key decisionmakers (5), namely, the company's General Administrator, the Head of HR, the Head of Real Estate, the Head of IT and the Program Manager of the transformation project. These interviews made possible to grasp the strategic positioning and the interests of the executive committee members, as well as their motivations for deploying a NWoW project within their organization.

To understand how the actors in charge of the local site positioned themselves with regard to the project, we followed the formal meetings held at the periphery every two weeks for a period of nine months (January 2018 to September 2018). Available data on local actors, therefore, stems mainly from direct and non-participant observations of eighteen strategic meetings. During the observation sessions, extensive notes were taken about the emerging issues, the actors' positioning, and the compromises being made. Meetings are indeed places where the players' strategies and conflicts of power are made visible for a watchful observer (Crozier \& Thoenig, 1976). Crucially, these meetings became the area where the actors of the local site exchanged and debated with the Program Manager of the headquarters.

\begin{tabular}{|c|c|c|}
\hline STAGE 1 & STAGE 2 & STAGE 3 \\
\hline $\begin{array}{c}\text { Interviews with members of } \\
\text { the company's Board (4) and } \\
\text { with the Program Manager (1) }\end{array}$ & $\begin{array}{c}\text { Non-participant observation of } \\
\text { the meetings held at the local } \\
\text { site (18 events) for a period of } \\
\text { nine months }\end{array}$ & $\begin{array}{c}\text { Additional interviews with } \\
\text { members of the local site (4) }\end{array}$ \\
\hline
\end{tabular}

Table 1 - Overview of the data collection process

The initial data on local actors was supplemented by additional interviews with key actors (4), including the supervisor of the local site of interest (named the "Intendant") and three top managers attending the meetings. These extra interviews were conducted to clarify specific interpretations arising from the observation of meetings. Finally, the dataset also included a set of internal documents collected during the fieldwork (17), such as minutes of meetings, PowerPoint presentations, and various work documents used by the field actors. These documents were occasionally consulted to strengthen and support our research interpretations.

\section{Data analysis}

A five-dimensional analytical framework was designed and used to perform a discursive analysis of the available data. On the basis of methodological recommendations from the coalitional perspective of organizations (Crozier \& Thoening, 1976; Pfeffer \& Salancik, 1977), a successive account was made of (1) the actors involved in the process, (2) their interests and objectives, (3) the power sources and resources they drew on to reach their objectives, (4) the strategies that they deployed while bargaining, and (5) the eventual outcome of the negotiation process. Such a framework allowed for a 
more accurate narration of the case study while retaining only the most insightful information relative to the power games at hand.

\begin{tabular}{|l|l|}
\hline \multicolumn{1}{|c|}{ STAGE } & \multicolumn{1}{|c|}{ DECISIONAL OUTPUT } \\
\hline Obtaining a cooperative agreement & $\begin{array}{l}\text { Organization of a meeting between the } \\
\text { Taskforce and the representatives of the local } \\
\text { site }\end{array}$ \\
\hline Uncovering the actors' interests & $\begin{array}{l}\text { Creation of a dedicated working group for } \\
\text { solving the issues of the local site }\end{array}$ \\
\hline Structuring the cooperation & $\begin{array}{l}\text { Elaboration by the working group of a proposal } \\
\text { of workspace redesign to submit to the } \\
\text { executive committee }\end{array}$ \\
\hline Facing the executive committee & $\begin{array}{l}\text { Approval for allocating a budget to the local site } \\
\text { for its workspace reorganization }\end{array}$ \\
\hline Twisting the transformation project & $\begin{array}{l}\text { Agreement among the local sites' } \\
\text { representatives on the way to invest the } \\
\text { financial resources received }\end{array}$ \\
\hline
\end{tabular}

Table 2 - Structuration of the data around five stages

In a second phase, and based on the available material, we identified five key moments structuring the NWoW project. These five moments, summarized in Table 2, correspond to five specific sets of controversies which were debated in the course of the negotiations. Moreover, each of these moments ended with a concrete act of decision making. In the following section, we introduce the case study, which is organized around the five moments illustrated above and which articulates the five conceptual elements issued from the literature on power in organizations (the actors, their objectives, the power sources, the strategies, and the negotiation process).

\section{The Gallic Village}

The case study features a public media company - "PMC" - of approximately 2000 employees. As a media company, PMC is charged with two main missions: the production of audio-visual contents on the one hand, and the diffusion of these materials through a variety of media such as television, radio and the Internet. The headquarters - "Dollet" - host a thousand workers as well as the executive committee which, chaired by the General Administrator, is the highest decision-making organ of the company. While strategic decisions at PMC are taken at Dollet, the organization encompasses several smaller local sites that have their own historical specializations: "Timber", the local site of our interest, is the main producer of entertainment shows and employs two hundred workers. In 2014, the executive committee made the decision to implement a transformation project that would involve redesigning a new building for Dollet, developing a new organizational model, and upgrading the company's technological equipment:

"Our organization is impacted in several ways by what is commonly called the digital revolution. Content dematerialization, (...) the abolition of physical constraints related to broadcast capabilities (...), an abundance of international concurrence (...), the revolution on 
what has been called the on-demand media (...) Within the executive board, we had the shared conviction that we had to rethink our strategic position and our organizational model" (PMC's General Administrator)

Initially, the transformation program primarily aimed to rebuild the headquarters of the firm (Dollet). The project would mainly be conducted and designed by the "Taskforce", a group of top managers from Dollet who were, for the most part, direct subordinates of PMC's executive committee's members. Over the following months, a series of escalating events caused the project to grow in complexity and in ambition. A report commissioned by the executive committee to a consultancy firm in August 2016 revealed important issues of dissatisfaction, absenteeism, cases of burnout, as well as discontent towards the management and the company's governance. The general administrator, who received these results "as a slap in the face" (HR Director), decided that the building project had to evolve into a "major transformation project" (General Administrator). The project was renamed and extended to become a NWoW project comprising flexible workspaces, a pilot project of remote working, principles of "participative" governance, and a "cultural transformation". Consequently, by the end of 2016, the Taskforce had grown in size and complexity, as multiple working groups responsible for the development of specific aspects of the NWoW project (such as implementing remote working and designing the new building) were created. As illustrated in Figure 1, the paper investigates the ensuing dynamics of bargaining between PMC's headquarters, Dollet, and one of its local sites, Timber, after it was confronted with the executive committee's transformation project.

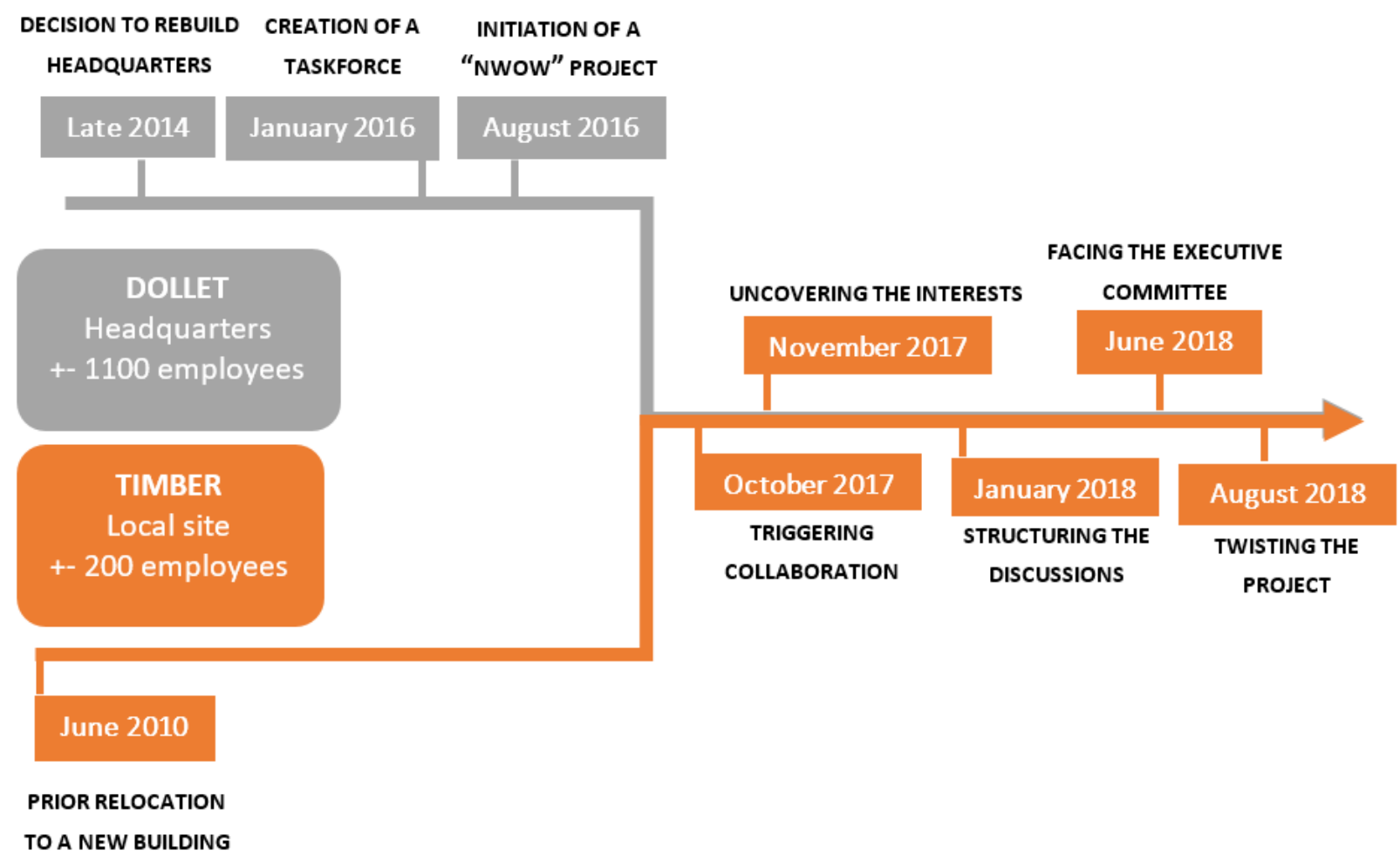

Figure 1: Timeline of the NWoW project

\section{Triggering collaboration}

Until October 2017, the transformation project remained the exclusive purview of the Taskforce and the executive committee. For a year, the Taskforce had made progress on multiple plans, including designing the new building, preparing a remote working policy, and developing a strategic vision for 
the years to come. Timber's involvement into the project was triggered by an informal meeting between Timber's "Intendant" - the local manager in charge of Timber's site supervision - and PMC's General Administrator:

"I first talked to the General Administrator, I said, we have ongoing discussions at Timber, and they might relate to the transformation project, what should we do? (...) He immediately said, go ahead." (Timber's Intendant)

As a result of this informal discussion, an exploratory meeting between the Taskforce and representatives from Timber was scheduled two weeks later, with the formal aim of "fueling the discussions about the new building with feedbacks from colleagues working at Timber" (Internal email). It should be mentioned that Timber's workforce had been relocated seven years prior (see Figure 1) and was since then working in open spaces offices, a spatial transformation that the Taskforce was seeking to implement, in the future, in the new building of Dollet. Several Taskforce members had already emphasized that "hearing from Timber experience would be useful for the change project conducted at Dollet" (Dollet Television Manager). The remaining doubts around the architectural choices to make regarding the open and non-attributed workspace of the future building made a case for cooperation between Dollet and Timber.

\section{Uncovering the interests}

The meeting gathered seven representatives from Timber, including Timber's Intendant, as well as two members of the Taskforce, among which the Program Manager in charge of the NWoW project. The discussions quickly revealed the deep dissatisfaction of Timber's workers with their actual workplace. Multiple problems, Timber representatives argued, still persisted in the building: the workplace was too noisy and "hindered creativity", the IT solutions were deemed unsatisfactory, the space was "impersonal" and "clinical", and employees had no control over lighting and heating. Other problems were mentioned, such as the lack of parking spaces, a growing feeling of estrangement between colleagues, a strong demand for brainstorming rooms, whiteboards and tools promoting collaborative work. Furthermore, the relocation process that took place seven years ago at Timber was described as a "major trauma" for the employees (Timber's Real Estate Manager), an "unaccompanied process of change that left many people wary towards transformation projects" (Timber's Intendant).

The issues identified by Timber's representatives were obviously at odds with previous communications from the Taskforce and the executive committee, which had overtly emphasized the ambition of the company to develop "a new company culture" and "modern working environments" (internal communication brief). As a result, Timber's concerns could not reasonably be left unanswered. While sharing their experience, Timber representatives had never intended to deter the Taskforce's plan for open spaces offices in the new Dollet building. Rather, what they were asking for was to be included in the transformation project in order to be given means and resources to solve the issues that they had just raised. The initial and formal aim of the meeting, "hearing from Timber's experience", effectively turned into "answering Timber's concerns", a much more interesting output for Timber's Intendant and her colleagues.

However, a critical question was left pending for Timber's representatives: how would the Taskforce members react to their complaints? Particularly crucial was the positioning of the Program Manager, who was in charge of steering the Taskforce and had privileged access to the executive committee. The Program Manager himself was in a delicate position. Other Taskforce members had previously 
underlined the importance of hearing about Timber's experience with open space offices. In line with the executive committee, who had stated that the transformation project had to become "global" and "not limited to Dollet" (General Administrator), the Taskforce had further warned against the risk of signaling that "Dollet came first once again, at the expense of the other sites" (Taskforce Member). Since the top management of Dollet had clearly expressed their concern regarding the bad publicity that could result from the local sites' perception of being left aside from the project, the Program Manager could not reasonably dismiss Timber's representatives. He concluded the exploratory meeting by agreeing on the need for Dollet and Timber to work together, stating that their feedback illustrated "a clear need for support in change management".

\section{Structuring the discussions: Timber's working cell}

At first, the episode of the exploratory meeting might look like an unambiguous victory for Timber. Their representatives had come with claims related to their own building, which were initially out of the formal scope of the NWoW project, and they had seemingly succeed in convincing the Program Manager of their right to be part of the project's structure. For his part, the Program Manager had temporarily avoided the threat of upsetting a major local center. However, two critical uncertainties remained, the first one being the financial resources. Indeed, although the executive committee's members had been very clear on the necessity of including the local sites in the transformation project, they had not guaranteed that a specific budget would be available for doing so. The Program Manager could therefore not reasonably promise any kind of financial support to Timber. A second difficulty for the Program Manager was to ensure that Timber would effectively follow the change guidelines issued at Dollet in order to ensure the consistency of the transformation program. To keep control over the cooperation process, the Program Manager suggested creating a specific "working cell" to tackle Timber's problems, which would be formally recognized within the project team structure (as shown in Figure 2).

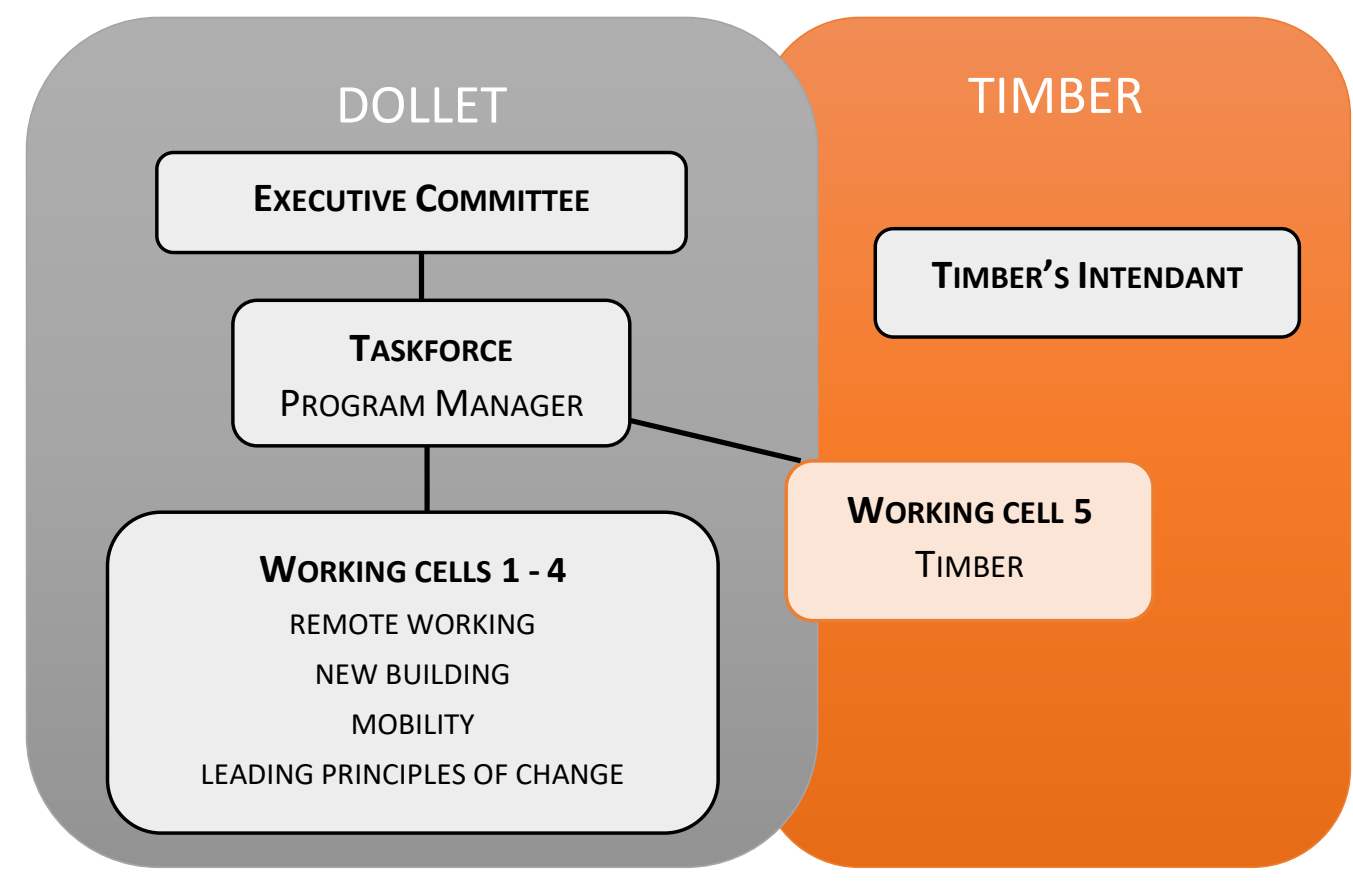

Figure 2: Formal structuration of the cooperation between Dollet and Timber 
As Figure 2 illustrates, the negotiation process between both sites would take place in a "working cell" that was put under the direct control of the Taskforce - itself steered by the Program Manager. The meetings of Timber's working cell would be organized in Timber's offices, and would gather a dozen representatives from Timber's directions, Timber's Intendant as well as the Program Manager. That way, the Program Manager could ensure that the decisions taken by the working cell would align with the Taskforce's goals. As the excerpt below illustrates, the "rules of the game" were quickly clarified during the first meeting of the working cell that occurred in January 2018:

"We start with a blank page, with a minimal framework to follow, a framework made of the leading principles of the transformation project that has been validated by the executive committee (...) I suggest to begin with two questions: one, what could we do here without any budget, or with minimal investment? Two, if we had a budget, what could we do with it? The idea is to submit a solid proposal to the executive committee in six months." (Program Manager, Observation notes, January 2018)

Having to work under the assumption that no budget was guaranteed and to operate within the limits of the framework designed at Dollet, Timber's representatives quickly realized that their room for maneuver was severely restricted. Was it worth to invest six months of time and energy into designing a project that could eventually be turned down by Dollet' executive committee? Not all of them appeared to be convinced by the exercise:

Program Manager: "The General Administrator wants to give maximum opportunities to the local sites. At the same time, you have to realize, the investments for the new building of Dollet will be colossal".

IT Manager (Timber): "We need to build awareness at Dollet, to show them that Dollet is not all that matters. If the General Administrator wants the company to change, he must realize that the company is not Dollet. People here at Timber must feel they are a part of the process. There should be a small, symbolic budget for Timber at the very least."

Real Estate Manager (Timber): "I agree. If we had not waved our flags, we would not even be around this table right now" (Observation notes, January 2018).

Timber's representatives did not immediately agreed to the terms of the collaboration suggested by the Program Manager, and threatened to withdraw from the project. The Intendant had to play a pivotal role to convince her colleagues to stay engaged in the change process. She immediately agreed to work together with the Program Manager, endorsed the transformation project's framework, and took the financial uncertainty as an unavoidable given. She eventually managed to convince her colleagues who, despite their initial reluctance, formally accepted the rules of the Program Manager. The Intendant saw in the newly created working cell the opportunity to make the different directions of Timber work together with Dollet. To her, it seemed that the integration of Timber in the project was already a success in itself, whether or not the working cell could deliver a project six months later:

"There is a primary objective to all of this, that is, we have to become actors of the company's transformation (...) I have a second, more personal motivation. Ten years ago, Timber and the other production centers had a total liberty, they could decide, I am going to produce this broadcast, to stream this theatre play... We had our independence, well, some people even thought we were like a barony, a Gallic village, if you will. Ten years ago, the General Administrator put a stop to all of this. All of a sudden. Two years later, people moved to this building, and again, they were not accompanied (...) Ever since, there is this strong feeling of weariness, this pervasive idea that whatever happens, Timber 
is not consulted and not listened to (...) So when I heard about the transformation project, I thought... This is an opportunity for us to take our destiny into our own hands... I would not say this to my colleagues, but if nothing changes here, it does not really matter, I mean, our building is far from being uninhabitable! What matters is the process, to prove that we can do great things when we think of ourselves as being part of the same company." (Timber's Intendant)

Meetings of the working cell, during which Timber representatives began to design their own change project, began to be held every two weeks. It should be noted that financial resources were a crucial issue for Timber, mainly because of the absence of transversal budgets at the local sites' disposal. Without financial support from Dollet, there would be no choice other than for Timber to charge the budgets required to carry out the NWoW project on a specific local direction - either the real estate, the IT, or the businesses (TV, radio, and web) themselves. In other words, faced with a project that supposedly impacted businesses, space and technologies at the same time, Timber had no transversal budget to rely on. Obtaining financial support from Dollet was therefore an aim shared by all Timber's representatives. However, Timber's representatives differed on what the proposal made to the executive committee should entail.

To assuage these doubts and channel the debates within the working cell, the Intendant relied on the transformation project framework elaborated by the Taskforce. Supported by the Project Manager, she made it clear that the working cell had to formulate proposals that were consistent with the ideas conveyed by the "New Ways of Working", which notably emphasized the ambition to implement nonattributed (or so-called "flexible") and activity-based ("dynamic") workspaces:

"We provide sufficient and shared workspaces. They are flexible, ergonomic, non-attributed on an individual basis, and in adequacy with the various activities we do (concentration, collaboration, relaxation, creativity, and well-being)." (Excerpt from the "Leading Principles of PMC's corporate culture and workspace environment", internal document).

As a consequence, several desiderata were excluded from the working cell's consideration, such as the issues related to the airflow system or to the parking solutions. Over the weeks, the working cell began to design their budgetary proposal which mostly revolved around the implementation of a nonattributed and activity-based workspace. Their scenario, in line with the leading principles of the transformation project, included new types of spaces, such as creativity, concentration, and meeting rooms, as well as coffee corners on every floor. The working group also requested new technological tools, such as docking stations on every desk, touchscreens, and videoconference equipment. In June 2018 , the group was finally ready to submit their budgetary proposal to the executive committee.

\section{Facing the executive committee}

The Intendant had prepared the ground for facing the executive committee by building strategic alliances beforehand. First, as she had more or less faithfully endorsed the transformation program's framework, she had quickly gained support from the Program Manager. As a reminder, the Program Manager had two major concerns: avoiding the discontent of the local sites, and ensuring the overall consistency of the transformation project. Insofar as the two scenarios suggested by the working cell were in line with his own objectives, he began to promote and exemplify the "serious work accomplished by Timber" (Program Manager, observation notes, May 2018). Second, the Intendant sought to maintain direct contact with the General Administrator and kept him informed on a regular basis. Third, she solicited the support of the IT Director of Dollet, an executive committee member 
who became the formal "sponsor" of Timber's working cell. A "sponsor", within the transformation project's structure, was a member of the executive committee who followed the works of a specific working cell to ensure that it was heading in the right direction. The Intendant thus had the opportunity to introduce the budgetary proposal to the sponsor before defending the project in front of the executive committee.

Despite the efforts of Timber's Intendant, the power struggle for obtaining a budget was far from being won, as the executive committee's positioning had so far remained ambiguous to say the least. On the one hand, there was a strong concern among its members for including the local sites in the transformation project; on the other hand, some of them were not, a priori, necessarily convinced by Timber's arguments:

"Timber has been served long before Dollet. They have a new building that has six years of age, they have a new infrastructure with a wonderful production studio... So our priority now is to work on the new head office of Dollet" (Executive committee's member, May 2018)

"Every reasonable person understands that we need to rebuild Dollet. This will be expensive. And now, suddenly, out of nowhere, Timber says, hey, do not leave us behind! (...) Taking care of Timber and investing at Timber are two different things. We said, we will take care of Timber, and we will do it. Now they ask for a budget... I mean, this is the result of a problem of framing. We said, we want to include the local sites. Very well. But then we do not know who has a budget to do so, not even if there is one!" (Executive committee's member, May 2018).

Despite the reluctance of some members of the executive committee, the decision was eventually taken to grant a budget equivalent to what Timber was asking for in its proposal. The executive committee underlined the "rigorous work accomplished by the working cell" (internal document), and both the General Administrator, the Program Manager and the sponsor of the working cell now seemed to fully support Timber. Naturally, the announcement was very well received by the working cell, and the Intendant immediately suggested working on the planning and the phasing of the project.

\section{Twisting the transformation project}

As soon as financial resources were put at the working cell's disposal, the Intendant communicated towards Timber's staff about the transformation project. Following the information sessions that were organized, it appeared that no one, not even the Intendant, was entirely convinced of the necessity of adopting flexible office policies:

"Flexible desks are a real black spot. We have a team working on a broadcast, they are young people, not old dinosaurs, they are doing great work in an open space. And when you talk to them about flexible desks... Well, it goes against their needs (...) So, embarking the staff will be difficult. Especially since I do not believe at all in the virtues of complete flex offices. In fact, I only pretend to support flex desking, even in front of my managers, but I am not convinced at all." (Timber's Intendant, August 2018).

Despite having won the support of the executive committee and unlocked the financial resources they were asking for, Timber's representatives were trapped by the transformation project's framework that they had endorsed. No one at Timber was really asking to implement flexible desks: their initial request was to obtain a budget to improve their workspace. However, because they were now formally a working cell operating under the Taskforce's control, Timber's representatives had to deploy the project according to the leading principles, which included non-attributed and activity-based spaces. 
As such, the next step for the working cell was to progressively and carefully move away from those leading principles:

Intendant: "I am already receiving questions such as, why should I clean my desk every day when I know I will be there again the next day? To be honest, I find it difficult to find a convincing answer."

Timber IT Manager: "Well, clearly, there are also people who should always stay at the same place, such as the planning and management teams."

Intendant: "That is not really in line with the leading principles. We should be more elusive in the words we use."

Timber Real Estate Manager: "We could maybe speak of workstations of specific nature? I mean, for each person who we think should have a dedicated place..."

Intendant: "I like the idea. Generally speaking, I think we should understand the basic intents of the leading principles, rather than strictly apply them. So, what I suggest to do, is that, between us, without showing it to anyone else, we put names on the plans, and we situate those workstations of... specific nature... So that we have a clearer view on, who is going where?" (Observation notes, June 2018).

The notes above illustrates how Timber's representatives were able to play with the leading principles and twist them into their own transformation project without arousing the suspicion of Dollet, in order to satisfy the employees. The fact that Dollet had not yet applied their own leading principles, since their building still needed to be entirely redesigned and rebuilt, left room for interpretation in the way the principles should be enforced. The working cell managed to regain some autonomy and to take additional liberty regarding the uses of the budget they had received from Dollet. When the time came to give information sessions to the entire staff of PMC Timber, the Intendant wrote a document for all speakers that contained the following piece of information:

"About the leading principles: we should all be aware that there is a difference between those principles and our everyday reality. What matters is to respect the spirit of those principles without applying them to the letter (...) We should avoid having a charter of obligations: a "military implementation" of NWoW workspaces has never worked well" ("Timber Tour", internal document redacted by Timber's working group, September 2018).

Timber thus managed to invest resources provided by Dollet into improving their workplace while limiting the discontent of their employees. In the end, around a third of the budget was used for acquiring extra furniture to create concentration and creativity rooms; another third was dedicated to the partitioning of those spaces; the last third was invested in technological equipment, sandblasted glass dividers, and acoustic improvements. The final compromise seemed satisfying for all the actors around the negotiation table. The executive committee managed to rally a major local site to its transformation project while investing a limited amount of resources into the process. The Program Manager successfully created a working cell supervised by the Taskforce, while avoiding contestation and contenting both the executive committee and Timber representatives. The Intendant demonstrated the benefits of cooperating between sites, hence temporarily alleviating the historical tensions between Timber and Dollet, and managed to inscribe Timber in the transformation project's agenda without generating excessive frustration among Timber's workers. By obtaining financial support from Dollet, Timber managers were rewarded for their six months of preparation and were even granted some freedom in the way those financial resources could be invested. 


\section{FINDINGS: DISRUPTION, INTERMEDIARIES, AND PARTICIPATION IN NWOW PROJECTS}

The primary aim of the paper was to offer an empirical investigation of the change process underlying a NWoW project in a multi-site media company by emphasizing politics and power games. Three main findings emerge from the analysis of the case of PMC. First, the capacity of local and peripheral actors to disrupt the plans of the deciding authorities of the organization and to significantly alter the ambitions of a NWoW project is highlighted. Second, the story of Dollet and Timber reveals the central role of specific actors or "intermediaries" who largely contribute to develop the project by carrying negotiations, finding compromises, and investing time and resources into the change process. Third, the case illustrates some interesting limitations of a participative implementation of a NWoW project. These three findings are exposed and summarized below. The theoretical and research implications of the paper are discussed thereafter.

\section{Local actors as disruptors of NWoW projects}

First, the case reveals substantial gaps between the managerial plan to initiate a NWoW project on the one hand, and the actual outcomes and consequences of the project for Timber on the other hand. In the course of the change process, multiple conceptions of NWoW emerge and collide. For the executive committee, NWoW is mainly a means to rebuild the headquarters and to spark a "cultural" transformation. The Intendant views in NWoW an opportunity to claim financial resources and to create a space for collaboration between Timber and Dollet. For the Program Manager, NWoW is a framework used to control the activities of the working cells, a set of leading principles to ensure that actors are working towards the same goal. Timber's representatives, for their part, mainly view NWoW as an annoying constraint that they have to bypass cleverly in order to obtain a transversal budget. The case of PMC reveals the political logics of appropriation underpinning a NWoW project. To state that none of the aforementioned logics matches the canonical definitions of NWoW would be an understatement. At best, the leading principles promoted by the Program Manager may be viewed as the most faithful illustration of what is commonly understood as "NWoW" - they include flexible and non-attributed workspace, technological evolutions, and governance changes. However, these leading principles, which are supposed to be the formal instrument guiding NWoW implementation at PMC, appear to be constantly diverted, distorted, and renegotiated by the actors themselves.

Deviations from the managerial plan do not simply occur without a reason: they result from the work performed by local actors who have their own agenda and objectives. Throughout the case, Timber representatives generate meetings, organize themselves, question the Project Manager, raise issues, make proposals, and attempt to rally a "sponsor" to their cause. Conversely, Dollet's members, whether the executive committee, the Program Manager or the Taskforce, appear to be much more passive and indecisive. It follows that the campaigning undertaken by Timber's Intendant and representatives turns the project into a homemade, revised version of NWoW, in which flexible offices are replaced by "attributed workstations of specific nature". Based on the sole observation of the final and stabilized result of the project, one might have concluded that the firm decided to reflect into their material workspaces a compromise between non-attributed desks and the specific nature of the work to perform. One might even have praised Timber for designing a "homemade", "adapted to the tasks" version of NWoW. However, such a simplistic conclusion largely overlooks the bargaining process taking place between the groups of actors involved and does not explain which resources and uncertainties were mobilized by these actors to amend the transformation project of the executive 
committee. A political analysis of the change process illustrates the crucial ability of local actors to twist and transform a NWoW project driven by the strategic management of the organization.

\section{Intermediaries in NWoW projects}

Specific actors appear to be vital for power games to occur and for NWoW projects to be deployed. Timber's Intendant is an indispensable change agent throughout the story. What makes the Intendant truly unique is her organizational positioning at the junction between Dollet and Timber. She is simultaneously in charge of the global management of Timber's site while being the privileged contact point with Dollet. Conversely, she is neither formally part of Dollet nor directly involved in most operational decisions taken at Timber. Therefore, she operates at the intersection of both worlds, an ambiguous position which is incidentally reflected through the job title "Intendant" itself.

From a change management perspective, it is interesting to note that the Intendant was at no point in the process formally mandated by the executive committee. Rather, she spontaneously stepped into the breach and actively sought to be part of the transformation project. By taking advantage of a discussion with the General Administrator, she is the one to argue for the importance of initiating a cooperation process. As Timber's working was is created, she federated and drove her colleagues, bargained with the Program Manager - another key intermediary, who had to juggle between the executive committee's demands, the Taskforce's works, Timber's requests, and his own ambitions for the NWoW project -, and built an alliance with a sponsor from Dollet to maximize the chances of convincing the executive committee. As soon as the budgetary decision was taken, she was once again on the frontline to make the project acceptable to Timber's managers and employees. Empirical evidence from the case thus seems to suggest the importance of key "entrepreneurs" or "intermediaries" in leading the negotiation process of NWoW projects.

\section{The unintended consequences of participation}

Finally, the case illustrates that adopting a participative approach of change management may open up additional bargaining opportunities for the local actors involved in a NWoW project. At first glance, PMC's executive committee has every resource it needs to remain in a position of force throughout the negotiations: decisional authority, strategic information and expertise, financial resources, and a dedicated Taskforce to carry out the transformation project. How to explain the subsequent overthrow of power through which Timber ultimately manages to obtain financial resources as well as some degree of freedom to use them? The adoption of a managerial rhetoric promoting "sites inclusion" and "participative approaches" at the level of Dollet's top management generated considerable ambiguity, which left room for Timber's representatives to negotiate. This was notably illustrated by a quote from an executive committee's member, who spoke of a "problem of framing". In the name of "participation", members of the executive committee had to put aside their reluctances and to let Timber's representatives play some sort of loosely defined role in the project. Participation gave the Intendant and her colleagues a considerable room for maneuver in attempting to negotiate a better outcome for themselves.

Resorting to participative approaches to implement a NWoW project, then, seems to increase the opportunities for local and intermediary actors to negotiate its outcomes. It turned out to be difficult for Dollet to dismiss spontaneous manifestations of interest, such as the one displayed by Timber's Intendant in the case, while remaining congruent with the discourses of participatory governance previously endorsed. As a consequence, the Program Manager had to acknowledge the issues and 
complaints raised by Timber's representatives. In the end, the involvement of Timber into the NWoW project may be viewed as an unforeseen and unintended consequence of the adoption of a participative approach to change by Dollet's top management.

\section{DISCUSSION}

\section{Theoretical implications}

The original ambition of the paper was to conceptualize New Ways of Working as projects of organizational change revolving around power games. Research on organizational change has for long supported the idea that collective action, instead of individual decision makers, should become the preferred level of analysis (Cabantous \& Gond, 2011). With this in mind, the analysis of the PMC's case heavily drew on Crozier and Friedberg's conception of power as an instrumental relation through which actors exploit their margin of liberty for action and commit the resources at their disposal (1980). The paper provides valuable theoretical insights on the actors able to assert power, on the strategic opportunities resulting from participation, and on bargaining as a modality of exercising power.

Whereas prior research on organizational change has often examined the work done by "change agents" formally charged with the responsibility of planning and implementing change (e.g. Battilana \& Casciaro, 2012; Lines, 2007), it appears that actors a priori unrelated to a project may wield power if they have good reasons and means to do so. The case of PMC illustrates that, rather than resulting from dedicated change agents' efforts, the project outcomes are largely being defined by the intensive work accomplished by peripheral members of the organization. One could argue that Timber's representatives, through their integration within the project team, eventually become "change agents" themselves - which is exactly the wish of the Program Manager. However, that would require to substantially revise what a change agent is. Timber's representatives do not necessarily seek, for instance, to "overcome resistance from other members of their organization and encourage them to adopt new practices" (Battilana \& Casciaro, 2012, p. 381), nor to "stimulate, facilitate, and coordinate the change effort" (Lunenburg, 2010, p. 1). Rather, they opportunistically take advantage of an existing project for obtaining financial resources, and have little interest for the "New Ways of Working" or the cultural changes promoted by Dollet. Such an observation suggests that research on change projects should not be limited to the investigation of the work accomplished by the mandated project team or change agents. Actors who are not formally designated by the deciding instances - peripheral disrupters - may suddenly emerge and play a major role in the change process. Instead of examining how change agents may influence organizational members (e.g. Battilana \& Casciaro, 2012; Norskov et al., 2017; Specht et al., 2018), research may instead benefit from understanding how specific organizational members exploit opportunities and mobilize resources to influence change agents and the deciding instances.

Moreover, the study highlights the crucial role of specific intermediaries in the change process, whom we suggest to theorize as "opportunistic mediators". If Timber's representatives are able to negotiate in their favor, it is largely due to the Intendant, a central actor who is able to accommodate their interests with Dollet's ambitions. The Program Manager himself is acting as a reflexive relay between Timber and the executive committee. Rather than "change agents", both of them may be viewed as "mediators" who, by influencing the actions of other actors, manage to become indispensable in the change process (Callon, 1986; Pollack et al., 2013). Besides, if we assume organizations to be " $a$ tension-filled network of relations" (Ford, 2006, p. 197), change projects then require intermediaries 
able to navigate "between different and even contradictory logics of action" (Crozier \& Friedberg, 1980, p. 41). However, these mediators do much more than "just" mediate; they remain rational actors who seize projects as opportunities to push their own strategic agenda forward (Vallas, 2010). In short, describing these actors as "opportunistic mediators" better emphasizes the variety of their motives and aspirations. To theorize change processes as involving both peripheral disrupters and opportunistic mediators provides a more nuanced and faithful depiction of organizational change than a mere opposition between "decision makers" and "resisters".

It should not be forgotten that the whole change process at PMC went together with efforts to implement a "participatory governance". We argue that our research results challenge the existing literature on participative change management, which has often assumed that involvement would, somewhat mechanically, reduce organizational resistance (Erwin \& Gaman, 2010; Giangrecco \& Pecei, 2005; Lines, 2004). Such an assumption receives little empirical support in our study. Rather, the paper supports the idea that actors will only play the game of participation if they have good reasons to do so, and further shows that participation opens up new areas of bargaining, struggle, and conflict, rather than merely reducing resistance (Friedberg, 1988). In the literature, participation is still perceived as a strategy that is carefully deployed by the top management, who consciously decides to delegate involvement and participation "to stakeholders who they perceive as having valuable commodities" (Russ, 2008, p. 206). By contrast, in the present case, participation appears to generate a messy, uncertain arena in which organizational members find new opportunities to make claims and secure resources. If we assume that "participation causes politicization" (Crozier \& Thoenig, 1976, p. 559), then it logically follows that participative change management techniques by no means inhibit the conflicts of interests that participation aimed to prevent in the first place (Friedberg, 1988).

Lastly, the paper empirically supports the theoretical assumption that power is mainly expressed through bargaining (Crozier \& Friedberg, 1980). It is in the course of negotiations that the actors express their objectives, deploy strategies, and build compromises that make the project move forward. The paper adheres to a reciprocal-relational conception of power, in which the ability to make others comply with one's aims and objectives is determining (Friedberg, 1988). As a consequence, negotiations moments should be given priority in a research process aimed at understanding organizational change. Such a position radically differs from the rational-intentional perspective, in which managerial dominance takes the center stage and dictates the functioning of organizations (Ford, 2006). Conversely, in a relational view, it is not possible for leaders to "possess" power (Norskov et al., 2017). The actors taking part to the negotiations and gaining the best of these negotiations are the ones who are effectively able to exert power - whether these actors are formally assigned a role or not in the organizational structure or in the project structure. Such conclusions reiterate the benefits of adopting a political approach of organizations, as suggested by the strategic analysis (Crozier \& Friedberg, 1980) and by the coalitional view of organizations (Pfeffer \& Salancik, 1977).

\section{Implications for researching NWoW and NWoW projects}

The paper has theoretical and methodological implications for the study of NWoW-labelled change projects. In this section, an alternative agenda for researching these projects is suggested. It is argued that current studies of NWoW have developed a tendency to obscure or ignore the power relations and negotiations taking place in the course of the change process. Yet, our findings as well as previous research on organizational change processes have illustrated how local actors, far from being defenseless, could substantially weigh on the outcome of a change project (Crozier \& Friedberg, 1980; 
Finkelstein, 1992; Vallas, 2006). This observation has often been neglected in existing studies of NWoW, which often assume NWoW to be an immutable "concept" of some sort (De Leede, 2017; Ruostela et al., 2015), that would in some way impose itself upon organizational members. In contrast to these studies who view NWoW as a given and build on "post-occupancy" methods of data collection (e.g. Brunia et al., 2016; Gerards et al., 2018; Kok et al., 2015; Van Steenbergen et al., 2018), the suggestion made in the paper is to view NWoW as organizational change processes involving rational and opportunistic actors.

A commonly accepted definition of NWoW is that it consists of an "organizational mix of flexible work practices, managerial modes and organizational configurations of work (...) contributing to make workplace governance more democratic and transparent" (Taskin et al., 2017, p. 65). The analysis developed in the paper, however, seems to suggest otherwise. At no point during the empirical account does NWoW appear to be about "work practices", "managerial modes" or "work configurations". The empirical narrative rather shows that actors constantly work to reach compromises around a transformation project of which "NWoW" is nothing more than a label. The final compromise that emerges has little regard for the principles that are at the very heart of managerial discourses of NWoW, such as flexibility or transparency. Even before turning into an "organizational mix" of anything, NWoW is a mere ingredient of power games and negotiation processes among others, a discursive argument strategically exploited by the actors. The empirical evidence provided by this paper appears to be at odds with the canonical definitions of NWoW that may be found in the literature. The argument could be made that the existing definitions of NWoW have, to a large extent, remained too faithful to (and uncritical of) the popular, managerial conceptions of NWoW, and have so far downplayed the power games underlying the implementation process of NWoW projects as a result.

The case reveals that the elements commonly found in the managerial discourses on NWoW, such as non-attributed desks, remote working or participative management for instance, are not at the center of the change process leading up to so-called NWoW workspaces. What matters in NWoW projects are the power games taking place between the actors and the compromises that they eventually make. Existing literature on NWoW, however, continues to stick to popular conceptions of their research object in which managerial practices such as the well-known tryptic of Bricks, Bytes and Behaviors (Kok et al., 2015) take center stage, at the expanse of the actors themselves, who are given a much more passive and dull role in the analysis. As a result, instead of being considered as a political interest among many others, the managerial intention to design a NWoW project takes precedence in the analyses, and the interpretation of local actors' behaviors is restricted to NWoW-related dimensions: how they cope with remote working, what they think of non-attributed desks, and why they reject objective-based management. The paper argues that the task of studying NWoW cannot be reduced to the investigation of the dimensions claimed by the dominant managerial discourses to be relevant to the understanding of NWoW.

In conclusion, we argue that research would benefit from theorizing NWoW as a mere label used to initiate organizational change, hence renouncing to turn NWoW into a "concept" of its own. Such an alternative agenda builds on a relational conception of power, and assumes organizational members to be largely able and capable to define or redefine NWoW by themselves. Recognizing that NWoW is always the result of a local construction calls for methodological caution, as researchers should prevent themselves from censoring the actors or from framing the data collection process according to their 
own conceptions of what NWoW could or should be. Moreover, defining NWoW as projects of organizational change calls for processual approaches in which NWoW itself is a dynamic and everchanging construct - rather than a stable and given sort of workplace. We argue that a 1) political (Crozier \& Friedberg, 1980), 2) processual (Callon, 1986), and 3) constructionist (Czarniawska, 2001) approach to NWoW would result in more empirically informed research on the design and implementation of such projects in organizational contexts.

\section{CONCLUSION}

The aim of the paper was to offer a political study of a New Ways of Working change project by investigating the dynamics of collective action occurring in a multi-site media company. To this end, the negotiation process and the power games taking place between the headquarters and a local production site were examined for a period of nine months. While the empirical study reveals that the local site managers actively bargained for becoming a part of the transformation project, it also shows that the key issues structuring the negotiation process involved financial resources, historical tensions, recognition, sites' appeasement, and local issues unrelated to the dominant, managerial conception of NWoW. The empirical, concrete manifestation of NWoW in the case of PMC appears to be far away from what other case studies have illustrated, as it does not revolve around so-called innovative work practices and workplace settings, but rather around power games, struggles for resources, and uncertainties. These findings plead for a more political, constructionist approach of NWoW projects in organizations, in which what NWoW entails is not defined a priori by the researchers, but rather built from empirical observation of the negotiation processes taking place between the actors. 


\section{REFERENCES}

Alutto, J. and Belasco, J. (2006), "A Typology for Participation in Organizational Decision Making", Administrative Science Quarterly, Vol. 17 No. 1, pp. 117-125.

Aroles, J., Mitev, N. and De Vaujany, F. (2019), "Mapping themes in the study of new work practices", New Technology, Work and Employment, Vol. 34 No. 3, pp. 285-299.

Ashmos, D. and McDaniel, R. (1996), "Understanding the Participation of Critical Task Specialists in Strategic Decision Making”, Decision Sciences, Vol. 27 No. 1, pp. 103-121.

Battilana, J. and Casciaro, T. (2012), "Change agents, networks, and institutions: a contingency theory of organizational change", The Academy of Management Journal, Vol. 55 No. 2, pp. 381-398.

Bergeron, H. and Castel, P. (2015), "Les habits neufs du néo-institutionnalisme ? La redécouverte de l'ordre mésologique et de l'agency", L'Année Sociologique, Vol. 3, pp. 23-62.

Bijl, D.W. (2011), Journey Towards the New Way of Working. Creating sustainable performance and joy at work. Par CC.

Brown, M. and Cregan, C. (2008), "Organizational Change Cynicism: the Role of Employee Involvement", Human Resource Management, Vol. 47 No. 4, pp. 667-686.

Brunia, S., De Been, I. and van der Voordt, T. (2016), “Accommodating new ways of working: lessons from best practices and worst cases", Journal of Corporate Real Estate, Vol. 18 No. 1, pp. 30-47.

Cabantous, L. and Gond, J. (2011), "Rational Decision Making as Performative Praxis: Explaining Rationality's Eternel Retour”, Organization Science, Vol. 22 No. 3, pp. 537-586.

Callon, M. (1986), Some elements of a sociology of translation: Domestication of the scallops and the fishermen of St Brieuc Bay, in Law, J. (Ed.), Power, action and belief: A new sociology of knowledge?, London: Routledge and Kegan Paul, pp. 196-229

Castel, P. and Friedberg, E. (2010), "Institutional Change as an Interactive Process: The Case of the Modernization of the French Cancer Centers", Organization Science, Vol. 21 No. 2, pp. 311-330.

Crozier, M. (1961), "Human Relations at the Management Level in a Bureaucratic System of Organization", Human Organization, Vol. 20, pp. 51-64.

Crozier, M. and Friedberg, E. (1980), Actors \& Systems. The Politics of Collective Action. The University of Chicago Press: Chicago and London.

Crozier, M. and Thoenig, J. (1976), "The Regulation of Complex Organized Systems", Administrative Science Quarterly, Vol. 21 No. 4, pp. 547-570.

Czarniawska B. (2001), "Is it Possible to Be a Constructionist Consultant?", Management Learning, Vol. 32 No. 2, pp. 253-266.

De Leede, J. (2017), New Ways of Working: Antecedents and outcomes, Emerald Group Publishing Limited. 
Denyer, D., Parry, E. and Flowers, P. (2011), “"Social, "open”, and "participative"? Exploring personal experiences and organizational effects of enterprise 2.0 use", Long Range Planning, Vol. 44 No. 5 , pp. 375-396.

Dufresne, S., Jemine, G., Rondeaux, G. and Pichault, F. (2018), "Beyond flexibility: confronting normative and lived spaces of New Ways of Working", $8^{\text {th }}$ Organizations, Artifacts \& Practices workshop: "New Ways of Working: Rematerializing Organizations in the Digital Age", June 2018, Amsterdam.

Dyson, R.G. and Foster, M.J. (1982), "The Relationship of Participation and Effectiveness in Strategic Planning", Strategic Management Journal, Vol. 3 No. 1, pp. 77-88.

Elbanna, S. (2008), "Planning and participation as determinants of strategic planning effectiveness. Evidence from the Arabic context", Management Decision, Vol. 46 No. 5, pp. 779-796.

Erwin, D. and Garman, A. (2010), "Resistance to organizational change: Linking research and practice", Leadership and Organization Development Journal, Vol. 31 No. 1, pp. 39-56.

Finkelstein, S. (1992), "Power in Top Management Teams", The Academy of Management Journal, Vol. 35 No. 3, pp. 505-538.

Ford, R. (2006), "Open-processional change: Three principles of reciprocal-relational power", Journal of Change Management, Vol. 6 No. 2, pp. 193-216.

Friedberg, E. (1988), L'analyse sociologique des organisations. L’Harmattan : Pour n²8.

Garud, R., Hardy, C. and Maguire, S. (2007), "Institutional Entrepreneurship as Embedded Agency: An Introduction to the Special Issue”, Organization Studies, Vol. 28 No. 7, pp. 957-969.

Gerards, R., Grip, A., and Baudewijns, C. (2018), "Do new ways of working increase work engagement?" Personnel Review, pp. 1-33.

Giangreco, A. and Peccei, R. (2005), "The nature and antecedents of middle manager resistance to change: Evidence from an Italian context", International Journal of Human Resource Management, Vol. 16 No. 10, pp. 1812-1829.

Jemine, G., Dubois, C. and Pichault, F. (2017), "An infrastructural approach to "New Ways of Working" change projects". SASE $29^{\text {th }}$ Annual Meeting, Lyon.

Jemine, G., Dubois, C. and Pichault, F. (2019), "From a new workplace to a new way of working: legitimizing organizational change", Qualitative Research in Organizations and Management, 2019.

Kingma, S. (2018), "New ways of working (NWW): work space and cultural change in virtualizing organizations", Culture and Organization, pp. 1-24.

Kingma, S., Dale, K. and Wasserman V. (2019), "Organizational Space and Beyond: the Significance of Henri Lefebvre for Organization Studies", Routledge: London.

Kok, A., Esten, R. and Helms, R. (2015), "Knowledge sharing in the new world of work: Effects of the New Way of Working", Journal of Information Technology Services, Vol. 14 No. 2, pp. 315-335.

Lawrence, T. and Suddaby, R. (2006), "Institutions and Institutional Work", in Clegg, S., Hardy, C., Lawrence, T. and Nord, W. (Eds.), Handbook of Organization Studies, London: Sage, pp. 215-254. 
Leca, B., Gond, J., Déjean, F. and Huault, I. (2006), "Institutional Entrepreneurs As Competing Translators: a Comparative Study in an Emerging Activity", paper presented at the XVeme Conference Internationale de Management Stratégique, Genève.

Lines, R. (2004), "Influence of participation in strategic change: resistance, organizational commitment and change goal achievement", Journal of Change Management, Vol. 4 No. 3, pp. 193215.

Lines, R., Selart, M., Espedal, B. and Johansen, S. (2005), "The production of trust during organizational change", Journal of Change Management, Vol. 5 No. 2, pp. 221-245.

Lunenburg, F. (2010), "Managing change: The role of the change agent", International Journal of Management, Business and Administration, Vol. 13 No. 1, pp. 1-6.

Metz, X., and Noizet, F. (2017), "New Ways of Working. Reinventing the company", Wavestone White Paper.

Moll, F. and De Leede, J. (2015), "Fostering Innovation: The Influence of New Ways of Working on Innovative Work Behavior - An Explanatory Multiple Case Study among White-Collar and Knowledge Workers", in De Leede (ed.), New Ways of Working practices: Antecedents and Outcomes, Emerald Group Publishing Limited, pp. 95-143.

Nielsen, K. and Randall, R. (2012), "The importance of employee participation and perceptions of changes in procedures in a teamworking intervention", Work and Stress, Vol. 26 No. 2, pp. 91-111.

Norskov, S., Kesting, P. and UIhoi J. (2017), "Deliberate change without hierarchical influence? The case of collaborative OSS communities", International Journal of Organizational Analysis, Vol. 25 No. 2, p. 346-374.

Pardo-del-Val, M., Martinez-Fuentes, C. and Roig-Dobon, S. (2012), "Participative management and its influence on organizational change", Management Decision, Vol. 50 No. 10, pp. 1843-1860.

Pfeffer, J., and Salancik, G. (1977), "Organization design: The case for a coalitional model of organizations", Organizational Dynamics, Vol. 6 No. 2, pp. 15-29.

Pollack, J., Costello, K. and Sankaran, S. (2013), "Applying Actor-Network Theory as a sensemaking framework for complex organizational change programs", International Journal of Project Management, Vol. 31 No. 8, pp. 1118-1128.

Ruostela, J., Lönnqvist, A., Palvalin, M., Vuolle, M., Patjas, M. and Raij, A. (2015), ““'New Ways of Working" as a tool for improving the performance of a knowledge-intensive company", Knowledge Management Research \& Practice, Vol. 13 No. 4, pp. 382-390.

Russ, T. (2008), "Communicating Change: A Review and Critical Analysis of Programmatic and Participatory Implementation Approaches", Journal of Change Management, Vol. 8 No. 3-4, pp. 199-211.

Salancik, G. and Pfeffer, J. (1974), "The Bases and Use of Power in Organizational Decision Making: The Case of a University", Administrative Science Quarterly, Vol. 19 No. 4, pp. 453-473.

Salancik, G. and Pfeffer, J. (1977), "Who gets power and how they hold on to it: A strategic contingency model of power", Organizational Dynamics, pp. 3-21. 
Smollan, R. and Sayers, J. (2009), "Organizational Culture, Change and Emotions: A Qualitative Study", Journal of Change Management, Vol. 9 No. 4, pp. 435-457.

Specht, J., Kuonath, A., Pachler, D., Weisweiler, S. and Frey, D. (2018), “How Change Agents' Motivation Facilitates Organizational Change: Pathways Through Meaning and Organizational Identification", Journal of Change Management, Vol. 18 No. 3, pp. 198-217.

Taskin, L. and Ajzen, M. (2015), "Managing sustainable and innovative workplaces: NWOW, towards sustainable organizational performance?", Working paper: Louvain School of Management Research Institute, UCL.

Taskin, L., Ajzen M. and Donis C. (2017), "New Ways of Working: From Smart to Shared Power", in: Muhlbauer V. and Harry W. (Eds). Redefining Management, Springer, Cham, pp. 65-79.

Vallas, S. (2006), "Empowerment Redux: Structure, Agency, and the Remaking of Managerial Authority", American Journal of Sociology, Vol. 111 No. 6, pp. 1677-1717.

Van Steenbergen, E., van der Ven, C., Peeters, M., and Taris, T. (2018), "Transitioning Towards New Ways of Working: Do Job Demands, Job Resources, and Engagement Change?", Psychological Reports, Vol. 121 No. 4., pp. 736-766. 